Sydney, Australia. The wide scope of the scientific work carried out, together with its practical applications, is reflected in the Division's annual report for 1961-62, which includes sections on physics, food chemistry, microbiology, muscle biochemistry, meat, fish, eggs, plant physiology, fruits, vegetables and canned and dried foods (Pp. iii + 36. Sydney, Melbourne and Canberra: Commonwealth Scientific and Industrial Research Organization, 1962). Theories relating to heat and mass transfer when a fluid flows at a high velocity over the surface 'wall' have been the subject of further investigations. Work on beef showed that the pasteurization of hindquarters using hot water $\left(65^{\circ}-70^{\circ} \mathrm{C}\right)$ caused the destruction of $90-99$ per cent of psychrophilic organisms without serious effect on the appearance of the tissues. The storage and quality of fruit has been considered from a number of points of view, including investigation of the prevention of scald and post-harvest treatment against infestation due to the Queensland fruit-fly. Considerable attention has been devoted to the radiation sensitivity of the eggs and larvæ of the fly. Better control of the radiation dose has resulted from the use of a small underwater fuel element irradiator and cobalt- 60 source. Future projects will include the use of gas chromatography and infra-red spectrophotometry for the study of the volatile flavouring constituents of foods. Also the radioactive isotopes carbon-14, sulphur-35. calcium-45 and tritium are to be used in a study of the chemical and biochemical changes which take place in animal products.

\section{Science and the Human Condition: Public Lectures at Hatfield College}

For the third year in succession, and in response to public demand, the Teaching Staff Association of Hatfield Colloge of Technology has organized a series of eight public lectures on scientific and philosophical subjocts, taking as its general themo this year "Science and the Human Condition". The lectures are as follows: January 25, Dr. S. Lilley, University of Nottingham, "The Scientific Revolution and Industrial Processes"; February 22, W. J. P. Webber (Transport Salariod Staffs Association), "The Scientific Revolution and Industrial Organisation"; March 15, Prof. John Cohen (University of Manchester), "The Scientific Revolution and Leisure"; May 10 , Sir John Rothenstein (Tate Gallery, London), "The Scientific Revolution and the Arts"; May 17, Dr. P. F. R. Venables (College of Advanced Technology, Birmingham), "The Sciontific Rovolution and Education"; May 24, Prof. Colin Chorry (Imporial College of Science and Technology, London), "The Scientific Revolution and Communication"; June 7, Prof. C. F. Powell (University of Bristol), "The Scientific Revolution and Morals"; June 14, Prof. P. M. S. Blackett (Imperial Collego of Science and Technology, London), "Tochnology, Science and Wealth". The inclusive fee for the course is $30 s$. Further information can be obtained from the Secretary, Teaching Staff Association, Hatfield College of Technology, Hatfield, Herts.

\section{The Night Sky in February}

FuLt moon occurs on Feb. 8d. 14h. 52m. U.T. and new moon on Feb. $24 \mathrm{~d} .02 \mathrm{~h} .06 \mathrm{~m}$. The following conjunctions with the Moon take place: Fob. 8d. 06h., Mars $3^{\circ}$ N.; Feb. $20 \mathrm{~d}$. 15h., Venus $0.8^{\circ} \mathrm{N}$. In addition to these conjunctions with the Moon, Mercury is in conjunction with Saturn on Feb. 28d. 09h., Morcury being $0 \cdot 8^{\circ} \mathrm{S}$. Mercury is a morning star, but is not favourably situated for obsorvation from northern latitudes. Venus is also a morning star, rising at $4 \mathrm{~h} .45 \mathrm{~m} ., 5 \mathrm{~h} .00 \mathrm{mn}$. and $5 \mathrm{~h} .05 \mathrm{~m}$. on Feb. 1,15 and 28 , respectivoly. Its stellar magnitude is $-3 \cdot 8$; its distance increases during the month from 69 to 88 million miles, and the visible portion of the apparent disk increases from 0.545 to 0.661 . Mars is in opposition on February 4, and is above the horizon all night. It is at a distance of 62 million miles at opposition, when it has an apparent diameter of 14 seconds of arc and its stellar magnitudo is -1.0 ; it moves from Leo into Cancer on February 4. Jupiter sets about three hours after the Sun on February 1, and conditions later become unfavourable for observation. Saturn is too close to the Sun for obsorvation. Occultations of stars brighter than magnitude 6 are as follows, observations being made at Groenwich: Feb. 1d. 19h. 39.5m., +11 ${ }^{\circ} 445(D) ;$ Feb. 3d. 21h. $48 \cdot 8 \mathrm{~m}$., 104 Tau. $m(D)$; Feb. 4d. $21 \mathrm{~h}$. 08.3m., $\chi^{2}$ Ori. $(D)$; Feb. 5d. 22h. 17.5m., $\zeta$ Gem. $(D)$; Feb. 6 d. 19h. 10.2m., $85 \mathrm{Gem}$. $(D)$. $D$ refels to disappearance.

\section{Announcements}

Mr. C. C. Hentschex, formerly vice-principal of the Chelsea College of Science and Technology and recog. nized toacher of zoology in the University of London, has boen appointed principal, in succossion to Mr. N. M. Lightfoot, who died on November 20 (Nature, 197, 19: 1963).

THe first British pest control conference, organized by the Industrial Pest Control Association, will be held at Lady Margaret Hall, Oxford, during April I-3. Further information can be obtained from Mr. W. A. Williams, Industrial Pest Control Association, 86 Strand, London. W.C.2.

A general discussion on "The Structure of Electron. ically Excited Species in the Gas Phase", arranged by the Faraday Society, will be held at Queen's Colloge, Dundee, during April 2-3. Further information can be obtained from the Assistant Secretary, the Faraday Society, 6 Gray's Inn Square, London, W.C.1.

The Chemistry Division at Argonne National Laboratory expects to occupy its new 'hot' laboratory wing early this year. In celebration of this event, it is planned to hold a symposium on "The Transplutonium Elements" at the Laboratory in Argonne, Illinois, during May 15-17. Further information can be obtained from Dr. D. C. Stewart, Argonne National Laboratory, 9700 South Cass Avenue, Argonne, Illinois.

A UNITED Nations conference on "Application of Science and Technology for the Benefit of the Less Developed Areas" will be held in Geneva during February 4-20. Further information can be obtained from the United Nations, Geneva, or, concerning the British contribution, from Mr. D. Flook, Press Office, Department of Scientific and Industrial Research, State House, High Holborn, London, W.C.1.

THE tenth Easter school in agricultural science will be held at the University of Nottingham School of Agriculture, Sutton Bonington, during April 8-11. The school will be the first of three discussions on crop ecology and will be concerned with the potato crop. Further information can be obtained from Mr. J. D. Ivins, University of Nottingham School of Agriculture, Sutton Bonington, Loughborough.

THE sixteenth Laboratory Animals Centre congress will be held in the University of Clasgow during April 2-3. The programme will include: a method for producing hairless mico in largo numbers; further observations on the maintenance of a mouse colony for the production of suckling mice; use of inbred strains of mice for feoding trials; the establishment of a beagle colony for experimental purposes; the care of dogs used for research; some observations on the American opossum; the significance of laboratory animals in the toxicity testing of new drugs. Visits have been arranged to the Hannah Dairy Research Station, the Marine Biological Research Institute and the Veterinary Research Farm, Cochno, and the Veterinary School, Garscube. Further information can bo obtained from the Laboratory Animals Centre, M.R.C. Laboratories, Woodmansterne Road, Carshalton, Surrey. 